\title{
"The school band and the Kulturskole are a single 'thing"': Exploring co-production between the public sector and a non-governmental organisation
}

\author{
Per Ståle Knardal ${ }^{1} \&$ Karsten Selseth Landrø ${ }^{2}$ \\ ${ }^{1}$ NTNU/Norwegian University of Science and Technology; ${ }^{2}$ Stjørdal Municipal School of \\ Music and Performing Arts
}

\begin{abstract}
This paper explores how a non-governmental organisation, a school band, and the municipal school of music and performing arts (the Kulturskole) collaborate to provide music education. Drawing on the concept of co-production, this paper investigates a case where the Kulturskole and the school band jointly deliver and plan the service of music education. The findings suggest that co-production in this case was perceived to be beneficial in terms of both efficiency and learning. Other broader outcomes were also detected, such as a strengthening of social bonds in the local society. The findings further suggest that in order to make co-production work, it is necessary to establish well-functioning organisational structures and good communication and knowledge transfer between the participants. Hence, the results in this paper inform the development of co-production as a mechanism to bring together a variety of stakeholders in the delivery and planning of arts education.
\end{abstract}

Keywords: co-production; arts education; management; municipal school of music and performing arts; Kulturskole

Received: August, 2020; Accepted: June, 2021; Published: September, 2021

\section{Introduction}

Attention to co-production has increased in recent decades within public service areas (Bovaird, 2007; Bovaird \& Loeffler, 2012; Brinkerhoff \& Brinkerhoff, 2002; Najam, 2000; Osborne et al., 2016). One motivation for the increased attention is a recognition that tasks and challenges in society cannot be solved by the public sector alone, nor can society depend on the market as an alternative to the public sector. The public management literature has emphasised that co-production can improve

^Correspondence: Per Ståle Knardal, e-mail: per.s.knardal@ntnu.no

(C) 2021 P. S. Knardal \& K. S. Landrø. This is an Open Access article distributed under the terms of the Creative Commons Attribution 4.0 International License (https://creativecommons.org/licenses/by/4.0/), allowing third parties to copy and redistribute the material in any medium or format and to remix, transform, and build upon the material for any purpose, even commercially, provided the original work is properly cited and states its license.

Citation: P. S. Knardal E K. S. Landro. "“The school band and the Kulturskole are a single 'thing"”: Exploring co-production between the public sector and a non-governmental organisation" fournal for Research in Arts and Sports Education, 


\section{P. S. Knardal E K. S. Landrø}

service efficiency and quality (Gazley, 2008). Other reasons for integrating societal activities, such as non-governmental organisation (NGO) activities, into the public sector include the need to form strong social networks and communities (De Vita et al., 2001; Voorberg et al., 2015). As a result, it has become necessary to reinterpret the concept of service delivery within the public domain, whereby members of a community play a more significant role in shaping decisions related to public services and their outcomes (Bovaird, 2007).

However, co-production has received limited attention in the context of arts education, and this paper addresses this gap by investigating co-production between the municipal Kulturskole and a local school band (an NGO). The Kulturskole is regulated by law under section 13-6 of the 1997 Education Act (Lovdata, 2020). School bands in Norway have a long history, with the first bands established over a century ago. These bands have always been voluntarily organised, with parents organising the daily operations. The study accordingly considers governmental and non-governmental organisations as separate economic entities, and the starting point for this paper is to investigate how the gap between organisations holding different positions can be closed - corresponding to what Ostrom (1996) described as crossing the 'Great Divide'.

Against this background, this paper explores the characteristics and possible benefits of co-production within this segment of arts education. There has been increased interest in collaboration within the Kulturskole, and research in the Nordic context has suggested that collaborations have several positive effects, such as strengthening education and overcoming institutional barriers (Angelo \& Emstad, 2017; Brøske, 2017; Holst, 2016; Väkevä et al., 2017). However, the Nordic research is based on collaborations between primary schools and the Kulturskole, whereas this article addresses collaboration and co-production between the Kulturskole and a local school band. This paper hence includes a study of co-production between the municipal and professionally run Kulturskole and the school band that is organised by the students' parents. The municipality is responsible for facilitating the co-production, and the school band and the Kulturskole studied in this paper have worked together for more than 10 years and have developed their co-production during this time. Initially, the band was rather small and competed in the lowest division of regional band championships. Today, it is among the best bands in the top division and one of the largest bands in the region. The research design is based on a case study of co-production within the context of the municipality of Melhus, and the main data is based on how the participants in the study describe and experience the co-production. Accordingly, this paper investigates the following research question: What characterises co-production in the case of a Kulturskole and a school band, and how can the co-production be beneficial?

The remainder of the paper is organised as follows. The next section provides an empirical account of the Kulturskole, the curriculum and the school band, before outlining the concept of co-production. The subsequent section describes the research 
methods, before the case is analysed. Some concluding remarks are drawn in the final section.

\section{The Kulturskole, the curriculum and the school band}

The Kulturskole and the curriculum

The Norwegian Council for Schools of Music and Performing Arts (the Council) introduced the 'Curriculum Framework for Schools of Music and Performing Arts Diversity and Deeper Understanding' (the curriculum) in 2016 (The Norwegian Council for Schools of Music and Performing Arts, 2016). This was a milestone in Kulturskole's history. From the establishment of Kulturskole's predecessors - public music schools that were first established in the 1950s - the Kulturskole has reached several milestones. The most important of these may be those that were achieved in 1982, when the government decided to provide every municipality with funding to establish a Kulturskole, and in 1997, when the Kulturskole was included in the Education Act and became part of the national cultural infrastructure (The Ministry of Culture, 2013, p. 256).

The Council was established in 1973 and is today a member-, interest- and development organisation for municipalities that own and run the Kulturskole. The Council's central role is to ensure that everyone can access high-quality cultural education at a reasonable price, and that the Kulturskole is a cultural resource centre in their local community.

To meet the objectives stated in the curriculum, an important tool is collaboration, and the Kulturskole is responsible for initiating this. The curriculum states the following:

Schools of Music and Performing Arts have a particular responsibility for co-operating with primary and secondary schools, bands, choirs, local cultural clubs and teams, as well as volunteer and professional arts and culture organisations. (The Norwegian Council for Schools of Music and Performing Arts, 2016, p. 14)

The curriculum further states that it is key for the students' artistic development and motivation to participate outside the Kulturskole. It is hence imperative to co-operate in the cultural community as a whole to provide the students with a beneficial learning environment.

\section{School bands}

School bands have a long history in Norway. The Norwegian Band Federation was founded in 1918, following the establishment of the first school bands. Today there are more than 1,000 school bands in Norway (Korpsnett, 2021; Norges Musikkorps Forbund, 2021). Norwegian school bands are not an integrated part of the primary schools but are related geographically, and most often by name, to their local primary school. The school bands are hence not organised by the primary schools themselves 


\section{P. S. Knardal E K. S. Landrø}

but are independent organisational units. Instrument training was for many years the band's own responsibility (and remains so in some places), and was organised by parents, professional musicians, or older members of the band. School bands have always been independent organisations that are voluntarily run by parents. Parents organise the bands by establishing school band boards that include the parents. The boards are responsible for budgets, events, trips, uniforms, sheet music, logistics, instruments and, increasingly in the last couple of decades, collaboration with the Kulturskole with regards to individual instrumental training. The boards hence have a great responsibility, not least financially by, for example, being responsible for the costs of maintaining and purchasing instruments. Instruments are among the highest costs for bands since each musician in the band can borrow an instrument, the cheapest of which costs just under $€ 1,000$, while the price can go up to about $€ 5,000$. The school band in Melhus annually invests about $€ 10,000$ in instruments.

\section{Co-production in arts education}

A literature search on co-production in arts education provides very few hits, and we were unable to identify any relevant literature to inform this case. However, related research has been conducted under the labels of collaboration, partnership and the formal-informal divide, and in the following section we therefore discuss some of this literature before we consider the concept of co-production.

\section{Collaboration, partnerships, and co-production}

Overall, the motivation for joining forces in arts education is the pursuit of improving arts learning both to increase quality and to improve access to high-quality arts learning experiences in communities (see e.g., Bodilly \& Augustine, 2008; Bovaird \& Loeffler, 2012; Hallam, 2011; Robinson, 1998; Russel et al., 2013). Fostering collaboration and forming partnerships by bringing together everyone involved in arts education at a local level has been a central recommendation related to, for example, the music education agenda in England (Hallam, 2011). This is supported by findings that by providing opportunities to develop the range of enriched experiences and outcomes, something greater can be achieved than would be the case within the scope of one partner.

Some perspectives can also be drawn from research on arts education in the Nordic context. This research has mainly covered the collaboration between primary schools and the Kulturskole and accordingly has a different focus than that of co-operation as discussed in the present paper. However, some points made about co-production and collaboration in the arts education field provide some relevant perspectives. For example, Angelo and Emstad (2017) claimed that the intentions of collaborations from the state's perspective are often vague, but that there are some broad intentions of strengthening education, utilising teachers' competence in the best possible way and bridging the gap between primary schools and the Kulturskole. This is supported 
by Brøske (2017), who emphasised the intention of developing the Kulturskole as a resource centre via increased collaboration with other educational institutions. Other research underscores the importance of collaboration by taking an institutional perspective. For example, Väkevä et al. (2017) and Holst (2016) stressed that collaboration can be a means to overcome institutional barriers and to couple institutional specialisations. The present paper applies the specific concept of co-production to describe a form of collaboration in the arts education field. Use of this concept provides an opportunity to focus on the active involvement of the end users of the provided service (Voorberg et al., 2015), as elaborated in the following sections.

\section{The concept of co-production}

Co-production refers to a view of public services based on reciprocity and mutuality. This differs from the traditional view of public services, where it is considered that public officials design and provide public services to citizens (Bovaird \& Loeffler, 2012; Osborne et al., 2016; Pestoff, 2006). The literature on co-production has built on the seminal work of Ostrom (1972), who argued that public service organisations depend on the community for service delivery and hence articulated limitations of the traditional 'provider-centric' model. The succeeding discourse on co-production is concerned with how service user participation can be integrated into service planning and production, the basic premise being that co-production is essential and a core component of service delivery. Advocates of co-production claim that public service cannot be delivered without co-production (Osborne et al., 2016); co-production has accordingly become an imperative in public policy and development of the public sector (Voorberg et al., 2015).

Numerous qualities have been attributed to the concept. For example, Ostrom (1996, p. 1073) defined co-production as the 'process through which inputs used to produce a good or service are contributed by individuals who are not "in" the same organization'. The core argument when discussing the division between the state and civil society is that public service organisations depend as much on citizens for implementing policies as citizens depend on public service organisations (Osborne et al., 2016). The quality of a service process is hence shaped by the users' active or passive role in the service delivery process, and their ensuing experience of the process. Bovaird (2007, p. 847) developed a definition according to which user and community co-production comprises 'the provision of services through regular, longterm relationships between professionalized service providers (in any sector) and service users or other members of the community, where all parties make substantial resource contributions'. Central to these definitions is the view that co-production is a joint activity between professionals and the public.

The above conceptualisation of co-production also makes it possible to clarify what co-production is not (Boyle \& Harris, 2009). Co-production is not consultation: it is not about professionals asking people for their opinion before the service is handed back to the control of professionals. It is not about handing all management 


\section{P. S. Knardal E K. S. Landrø}

of services to the public either, as this would appeal only to the small number of participants who would need to be involved. Finally, co-production is not passive volunteering: the concept of co-production has equality at its heart and aims for more mutual exchange and transformation of power within public services.

\section{Objectives of co-production}

Interest in co-production increased following the 2008 global recession, as many governments made major cuts to public sector expenses (Bovaird \& Loeffler, 2012). Voorberg et al. (2015) claimed that effectiveness and efficiency are important objectives of co-production. On the other hand, they also argued that few studies mention specific objectives of co-production but suggested the involvement of citizens as a virtue in itself.

Bovaird and Loeffler (2012) provided more nuance by discussing how co-production can be value-adding. They argued that value in the public sector has several dimensions, such as user value, value to wider groups such as family or friends of service users, social value, environmental value, and political value. This provides insight into the motivations behind co-production. Users may become involved in public services to increase the quality of the service from a self-regarding perspective.

Accordingly, public services ought to be designed to provide not only results but also outcomes (Broadbent \& Guthrie, 2008). Voorberg et al. (2015) argued that if such a functional or goal-oriented approach is used, the outcomes of co-production can be somewhat disappointing. It is thus necessary to relate the outcomes to what citizens consider to be valuable (Bovaird, 2007).

\section{Influential factors}

Numerous factors influence co-production on both the organisational side and the citizen side. Voorberg et al. (2015) found that compatibility, attitude of openness towards participation, risk attitude and the presence of incentives influence the organisational side.

Compatibility refers to the presence or absence of fostering organisational structures in the public domain, or an appropriate infrastructure that enables communication with citizens. Another factor is the attitude of public officials. Citizens must be accepted as qualified partners, which may be an issue as politicians, managers and professionals may consider citizens unpredictable, such that co-production with citizens may reduce the latter participants' power status and control (Bovaird \& Loeffler, 2012). A risk-averse and conservative administrative culture can hence be a barrier to co-production as citizens can be perceived as unpredictable and unreliable (Voorberg et al., 2015). Maiello et al. (2013) claimed that the lack of precedent of seeing citizens as associates rather than service receivers means that the 'institutional space' does not perceive citizens as equal partners. An additional organisational factor is the presence of incentives for co-creation. As Voorberg et al. (2015) stated, the literature 
highlights the importance of clear initiatives for co-production as public officials may not clearly understand how co-production can improve services and generate budgetary benefits (Fuglsang, 2008).

Voorberg et al. (2015) also highlighted citizen factors that are central to coproduction. One factor is that citizens' characteristics are of great importance, as it is vital that citizens have intrinsic values such as loyalty, civic duty and a desire to positively develop their community and society. The level of education is also important, as people with higher education are more aware of community needs and are able to articulate their own needs. Another factor is awareness. A sense of ownership and the perceived ability of citizens to participate are conducive to co-production. Voorberg et al. (2015) understood social capital in a society as people looking after each other, and stated that this avoids people feeling that they are alone or in a minority position. Voorberg et al. (2015) further indicated that co-production is more easily applied in societies with high social capital. Bovaird and Loeffler (2012) claimed that coproduction is most common in countries with large welfare states.

\section{Research method}

This research focuses on a case study of co-production between the Kulturskole and a school band in the Norwegian municipality of Melhus. The Kulturskole and the school band were selected for this study because of the co-operation and co-production they have developed over a significant period of time. Melhus Kulturskole has shown innovativeness over many years, developing new structures of teaching and collaboration with, for example, bands, choirs, kindergartens, and elementary and middle schools. Melhus Kulturskole has also taken part in several development projects that have searched for new means of co-operation between schools, kindergartens, volunteers and the Kulturskole.

Melhus School Band comprises 70 musicians aged between 8 and 19. They practice twice a week, once with the entire band and once in the form of individual lessons in the Kulturskole. The band is divided into two levels, the main band and the beginner's band, in the latter of which the students play in their first two years of their music career. The band competes against other bands in annual regional championships. From their start in the lowest division, Melhus School Band have now risen to the top division and have become one of the best bands with the highest musical standards in the region.

Data collection for this research was conducted through a combination of semi-structured interviews, informal conversations, observations, and a short questionnaire conducted amongst the students. The focus, however, was on exploring co-production through the perspective of participants who have experienced this phenomenon in its actual context. The most used data source was hence the interviews.

A variety of participants were interviewed, and these were classified into three categories. The first contained teachers from the Kulturskole, including the co-principal. 


\section{P. S. Knardal E K. S. Landrø}

This is a relatively homogenous group as most of these informants have university or college education in the field of arts and play an instrument at a very high level. In addition, most have pedagogical education. In Norway, almost everyone who teaches wind instruments in the Kulturskole plays or has played in a band. This means that they have significant experience, and often a clear idea of how a band should be organised.

The second category of interviewees comprised board members of the school band. These are parents of students from the band, which means that their social background, education and experience with school bands may differ. This category is thus less homogenous than the first. The board maintains financial responsibility for the school band and has employer responsibility for the conductor. The board also organises all practical matters, such as sheet music, uniforms, instruments and trips. The board was interviewed as one group of six people. The decision to conduct a group interview with the board was made because of the board's diversity and the fact that some members lacked confidence in their knowledge about co-production. However, the group interview turned out to be beneficial as the researcher moderating the interview had the opportunity to encourage a conversation with the aim of obtaining data in what Frey and Fontana (1991) described as a natural setting.

The third category contained the leaders: the conductor and the principal of the Kulturskole and the chair of the board. The conductor, who has a university degree in music, has artistic responsibility for the band. The principal of the Kulturskole is the administrative and educational leader of teachers in the Kulturskole and has in this case the overall responsibility for co-production between the Kulturskole and the school band. The chair of the board can also be included into this category as this person has a leading role in the practical organisation of the band and sustains continuous dialogue with the other leaders. The chair of the board is a parent who is a volunteer, and is not necessarily professionally trained in either management or arts. The chair of the board was interviewed together with the rest of the board. The interviews lasted between 25 and 45 minutes; a summary of the interviews is provided in Table 1.

Table 1. Summary of interviews

\begin{tabular}{cl}
\hline Interview number & Position \\
\hline $\mathbf{1}$ & Flute teacher \\
$\mathbf{2}$ & Clarinet teacher \\
$\mathbf{3}$ & Trombone teacher/co-principal \\
$\mathbf{4}$ & Trumpet teacher \\
$\mathbf{5}$ & French horn teacher \\
$\mathbf{6}$ & Saxophone teacher \\
7 & Principal \\
$\mathbf{8}$ & Conductor \\
$\mathbf{9}$ & School band board \\
\hline
\end{tabular}


The interview guide was designed to capture the participants' perceptions of how this specific co-production works in practice. The interviewees were asked which areas of activity and roles were incorporated in their co-production. Another aim of the study was to gain an understanding of what they perceived as influential in making co-production successful, and questions were asked to obtain insight at both the organisational and the individual levels. The interview guide also included questions related to the perceived outcomes of co-production. The interviews were conducted in Norwegian, and the final quotes presented here have been translated by the authors.

The process of data analysis aimed to explore how the research problem, literature and data influenced each other, the result of which was to generate a plausible fit between these. No formal coding program was used for data analysis. First, the interview transcripts and the documents were read by the researchers. The theoretical framework was then established, after which the empirical material was organised and analysed by applying the themes and categorisations from the theoretical framework. Finally, the case analysis was carried out and compared to the theoretical framework and previous research to illuminate the specific aspects of this case. During the process of revealing patterns and connections, the authors constantly cross-checked the interpretations with each other to develop the best possible understanding of the studied phenomenon. Due to word count limitations of this paper, the full richness of the case study is difficult to convey. However, the authors had a strong awareness of this challenge and constantly aimed to include the data they felt would provide the best possible representation of this case in a transparent manner.

As elucidated above, the main body of data is based on interview responses. The findings are accordingly based on the personal statements from the informants. However, the interviews do not reveal personal and sensitive information that can be traced back to the participants, and thus participation in this study did not pose any risk of causing harm to the informants (Simons, 2009). Further, the intention of the study was not to criticise the participants, but to explore the concept of co-production and to broaden and develop understanding of this concept. Another ethical dilemma that had to be addressed is that one of the authors works in the cultural field and hence knows the participants involved in the study personally, and it can be argued that this distorted the critical distance to the investigated practice. However, the second author did not have any such knowledge of any participants, and the findings were critically discussed between the authors to prevent personal knowledge from interfering with the analysis.

\section{Case analysis}

The case analysis explores the co-production between the Kulturskole in Melhus municipality and Melhus School Band by building on the concept of co-production and its inherent terminology. 


\section{P. S. Knardal E্ K. S. Landrø}

\section{The curriculum in Melhus municipality}

The curriculum was passed at the national Council meeting in 2016 and has in the following years been implemented in Norwegian municipalities. To meet the objectives of the curriculum, the central overriding aims for the students are to build skills on their instruments, experience the joy of mastery and positive self-improvement, and develop a close relationship to music (The Norwegian Council for Schools of Music and Performing Arts, 2016, p. 47). One of the key measures in working towards these aims is the development of skills in collaboration with others in, for example, ensemble activities. The collaboration between the Kulturskole and the school band is based on the fulfilment of interaction and ensemble activities. The co-principal stated: 'I see the school band as the most important arena for ensemble activities we can have. We have no chance of getting anything better.' This illustrates that co-production is perceived as advantageous for the Kulturskole. The findings also suggest that economic factors are motivating:

We get a model that saves public money. The alternative [not co-operating] is to significantly lower the ambition level in both the band and the Kulturskole with the negative consequences it will have for both the children and the community. (Interviewee 3)

There are three areas of activity where co-production is particularly important: instrumental training, concerts and recruitment. The weekly instrumental training includes one individual lesson with a teacher employed by the Kulturskole, and one school band practice. A combination of individual tuition with a professional teacher of the instrument and ensemble training in the school band is perceived to be particularly effective. However, the development does not only result from individual and ensemble tuition; the individual and ensemble tuition are also integrated as the school band's sheet music is used in the individual lessons. This provides the students with help to quickly learn their sheet music and may hence be argued to provide students with the opportunity to achieve mastery more quickly and to develop to a higher musical level when playing in the school band with their fellow students. One of the teachers stressed the importance of this combination:

[One student] played very well, had a nice sound, and was engaged and positive during [individual] lessons. Then she quit the band but continued with individual lessons in the Kulturskole after the summer. She started out fine, but eventually I realised that by not playing in the band she stagnated. (Interviewee 1)

Concerts are the second area of activity. During a semester, $75 \%$ of students perform in three or more concerts. This means that there is always a concert to practice for. The findings suggest that the principle behind this is that it is easier to motivate students to practice when they have a clear goal in mind. There are both solo and ensemble concerts. Solo concerts are typically organised by the Kulturskole, whereas ensemble concerts are most often organised by the school band. However, the pressure this entails may be excessive for some students, so the Kulturskole and the 
school band spend quite a lot of time co-ordinating the overall concert activity for each student.

The last area of activity is the recruitment of new students. The Kulturskole and the school band depend on each other when it comes to recruitment as they both need new students every year. The pool of children from which they can recruit is also the same. Recruitment for the school band is conducted in collaboration with the Kulturskole, and several interviewees emphasised the importance of this process. 'It is important that we help the band with their recruitment concerts. The teachers sit in with the band during all the concerts around the municipality' (Interviewee 3). To recruit new members, the school band visits all elementary schools in the area; teachers from the Kulturskole participate in these concerts, playing along with the band, demonstrating instruments, and giving a face to music education.

Central to co-production is the rejection of the view that citizens are passive receivers of public services (Osborne et al., 2016; Ostrom, 1996); instead, the idea is that a co-produced public service comes from joint activity between professionals and the public. The instrumental training, concerts and recruitment are all jointly delivered by the Kulturskole and the school band. Boyle and Harris (2009) further claimed that for a process to be fully defined as co-production there must be active involvement from both sides in the design and planning of the service. The findings suggest that in this case the relationship between the Kulturskole and the school band includes mutual exchange in both the planning and delivery of the service. This appears to be what Boyle and Harris (2009) described as 'full co-production'.

\section{Outcomes}

The central aim of engaging in co-production is, as pointed out by Bovaird and Loeffler (2012) and Voorberg et al. (2015), the reduction of costs. The present study also describes the school band's stock of instruments, which are worth tens of thousands of euros, as a key asset for the municipality to comply with the curriculum. In addition, increased quality of the public service has been raised as a reason for co-production (Osborne et al., 2016). These findings also suggest that there have been numerous additional and positive outcomes of co-production (Voorberg et al. 2015). The teachers emphasised that from the perspective of music education it is important for students to have an opportunity to play music and perform in different settings. Although the principal would like students to play in even more settings, the co-production creates opportunities to perform music in a range of contexts.

As discussed above, co-production provides students with both individual training through instrument lessons with their teacher, and ensemble training in the school band. Experienced professional teachers have worked in settings both with and without co-production between the municipal Kulturskole and the local school band. The findings of the present study suggest that the perception among teachers is that, from an educational perspective, being part of the co-production is an advantage at the individual level. The school band has also raised its standards by engaging in the 


\section{P. S. Knardal E K. S. Landrø}

co-production. One aspect in support of this is the band's movement from the lowest to the top division in regional championships. The conductor said: 'The students who play in both the band and in the Kulturskole have a significantly better learning curve than those who only play in the Kulturskole.'

In addition, the findings suggest that co-production not only has the effect of developing the musical skills of students but also creates space for developing the community (Bovaird \& Loeffler, 2012; Voorberg et al., 2015). Having a large and prosperous school band in the community provides children and youth a means by which to interact with others who are of different ages and genders. Moreover, in this school band students meet across school districts. The findings also suggest that the school band is an important social meeting place for parents, since social bonds in the community are further strengthened at parties and other social gatherings. The conductor said: 'In recent years, and on my initiative, we have organised parties for parents. We meet in the barn [an old barn that has been turned into a party venue] and everybody brings something to eat and drink for sharing.' The board also underlined the importance of the band as a socialisation platform for parents:

The parents are very important. Parents in the band must have a good social time together. If not, then you are struggling to build a band. We must welcome new parents and create gatherings and parties for parents. (Interviewee 9)

Such social interaction was an effect of creating the band, but also a precondition for maintaining and developing it further.

\section{Influential factors}

The findings suggest that the most important communication platform among the participants is the meetings that are held twice per semester. The participants include music teachers, the conductor of the main band and the recruitment band, the chair of the school band board, and one or more representatives from the board of the school band. The joint meeting is a formal point at which important issues related to co-production are discussed. The trombone teacher said:

There are quite a few channels for information since the conductor works at the Kulturskole. The fact that you meet all the time is important as an informal channel, but the most important [information channel] is the joint meeting between the conductor, the school band, and the Kulturskole. This is the formal meeting point.

Certain issues are brought up in every meeting. Each student is discussed, and, if challenges are noted, measures for the student are agreed upon. Such challenges may include motivational struggles, or some more practical issues that can be resolved with the help of the teachers or the board. Another regular topic is the annual cycle of the school band, which is discussed and updated in every meeting. This issue is important since it raises awareness of the need for planning; for example, planning should prevent overload for students from scheduling too many concerts during a short period of time. The joint meetings are followed by staff meetings in the Kulturskole. 
These meetings are also vital for co-production as music teachers are provided with the opportunity to discuss issues at a professional level.

The findings of this study suggest that the chair of the school band, the conductor and the principal of the Kulturskole are the central driving forces of co-production. The conductor is perhaps the most significant driving force. He is a professional musician with a university degree in music, and his salary is divided between the Kulturskole (25\%) and the school band (75\%).

The principal of the Kulturskole established some basic structures for functional co-production that are in this case central. The partial employment of the conductor is the principal's responsibility, but the interviewees also perceived the principal and the Kulturskole to be flexible when it comes to integrating the two organisational units. The findings of the survey carried out among students, the end users of co-production, support the flexible and integrative strategy from the principal's side, as they perceive the Kulturskole and the school band not as two different entities, but as one 'thing'.

The chair of the school band board plays a somewhat more distanced role in daily co-production operations. However, as mentioned earlier, the school band is organised by volunteer parents, and several interviewees emphasised the importance of a well-functioning group of parents to secure the school band's obligations. The chair consciously works together with the board and the conductor to create a strong sense of community among the parents; as a result, the parents are very willing to engage in volunteer activities and the school band organisation is vigorous and strong. One of the teachers said: 'The school band is good because there are good people in all the roles and positions' (Interviewee 3).

The overall perception among interviewees is that the co-production works well and reinforces the overall aims of collaboration between well-functioning structures. Effective communication and knowledge transfer between the participants are perceived as key to achieving this. One member of the board said: 'We expect the principal and conductor to work with the chair and the board. It works so well that we have not had any challenges' (Interview no. 9).

Voorberg et al. (2015) suggested that both organisational and citizen characteristics influence co-production. The co-production in Melhus is driven by the responsibility stated in the curriculum, which is to co-operate with other cultural organisations in the municipality. Another reason is that it was too expensive for the Kulturskole alone to establish a platform ambitious enough for ensemble training. The school band represented a very good partner, with its well-functioning organisation, stock of instruments and solid economy. The school band was hence compatible with the Kulturskole (Voorberg et al., 2015). As noted above, studies have identified potential barriers that professionals in the municipality may face when co-operating with citizens, who may be viewed as unpredictable (Bovaird \& Loeffler, 2012). However, the findings of the present study suggest that the municipality and Kulturskole were open to collaboration with the school band as the school band had high credibility in the municipality and among the personnel of the Kulturskole. 


\section{P. S. Knardal E K. S. Landrø}

Voorberg et al. (2015) also highlighted the central characteristics on the citizen side that promote well-functioning co-production - namely loyalty, civic duty and the wish to positively develop their community. One of the interviewed teachers stated that there are effective people in all positions in the school band. This school band has a long history of being well-organised, and the findings suggest that the chair, the board of the school band and the conductor have made conscious efforts to create and strengthen the sense of community and ownership among parents of students in the school band. The findings also suggest that it is now easier to motivate parents to engage in volunteer activities as the school band is perceived as a strong organisational unit. Based on the above, we suggest that there are both organisational and citizen factors that support the functioning of this co-production.

The final point is that although the co-production examined here appears to be strong and healthy, there are some obvious risks. The school band is organised by volunteer parents of music students, who are primarily motivated by the relation to their own child and their local community. The ability and competence to maintain and develop all functions required for the school band will therefore vary between bands and communities. We hence support Bovaird's (2007) argument that there is a need for a new type of public service professional, the co-production development officer, who can help overcome obstacles to effective co-production.

\section{Concluding remarks}

The findings in this study suggest that the co-production between the school band and the Kulturskole has been beneficial in Melhus municipality. The study shows how co-production takes place in this context between public service professionals, service users and citizens in the community by describing how arts education is planned, designed, managed, delivered, and evaluated (Bovaird, 2007). One of the clearest findings is that good communication and knowledge transfer between participants is of particular importance. Communication in the co-producing organisations was well-structured and accepted by the involved participants. The findings also suggest that there is mutual dependence between the participants, and that the coproduction has been beneficial as it is perceived to be a means by which to improve the students' musical capabilities. The well-functioning integration of the Kulturskole and the school band indicates that, as a result of co-production, the Kulturskole and the school band are not perceived as two separate entities, but as a whole - a single 'thing'.

This paper is subject to caveats typical of single-case studies; for example, generalisation of the findings is difficult. However, some insights may still be drawn from the findings. This research contributes to the literature on co-production by showing how co-production among public service professionals, service users and their communities can take place in all phases of service delivery. Keeping these findings in mind, we suggest that co-production between users and communities may be 
beneficial for several purposes, such as efficiency, involvement and integration, and quality (Bovaird, 2007; Voorberg et al., 2015). Further, this paper contributes to the literature by investigating co-production in arts education. This paper shows that co-production can play a role in contributing to increased participation in, and quality of, arts activities. These general claims hence support other research on collaboration in arts education in the Nordic context (Angelo \& Emstad, 2017; Brøske, 2017; Holst, 2016; Väkevä et al., 2017). However, literature on the topic is still scarce, and further research on co-production is necessary to better understand and develop the concept within the arts education field.

\section{Author biography}

Karsten Selseth Landrø is the principal at Stjørdal Municipal School of Music and Performing Arts. He is educated at the Norwegian University of Science and Technology with a degree in music, pedagogy and conducting. He also holds a Master of Public Administration (MPA). He has worked as a conductor, music teacher, administrator, and musician, including as general manager of the Norwegian Association of Marching Bands in Trøndelag.

Per Ståle Knardal is associate professor in accounting at NTNU Business School. He holds a Master of Music in performance from Royal Northern College of Music, a master's degree in economics and business administration and a $\mathrm{PhD}$ in management accounting from NTNU. He has work experience as a musician, accountant, consultant, and festival director. He has published several articles in accounting in the field of arts and culture.

\section{References}

Angelo, E., \& Emstad, A. B. (2017). Skolekonsepter som blir til i samarbeid mellom grunnskole og kulturskole [School concepts that are created in collaboration between the primary school and the school of music and performing arts]. In E. Angelo, A. Rønningen, \& R. J. Rønning (Eds.), Forskning og utvikling i kulturskolefeltet. IRIS - den doble regnbuen (Chapter 11). Cappelen Damm Akademisk. https://doi.org/10.23865/noasp.21

Bodilly, S. J., \& Augustine, C. H. (2008). Revitalizing arts education through community-wide coordination. Rand Corporation. https://doi.org/10.7249/MG702

Bovaird, T. (2007). Beyond engagement and participation: User and community coproduction of public services. Public Administration Review, 67(5), 846-860. https://doi.org/10.1111/j.1540-6210.2007.00773.x

Bovaird, T., \& Loeffler, E. (2012). From engagement to co-production: The contribution of users and communities to outcomes and public value. Voluntas: International fournal of Voluntary and Nonprofit Organizations, 23(4), 1119-1138. https://doi.org/10.1007/s11266-012-9309-6

Boyle, D., \& Harris, M. (2009). The challenge of co-production. New Economics Foundation.

Brinkerhoff, J. M., \& Brinkerhoff, D. W. (2002). Government-nonprofit relations in comparative perspective: evolution, themes and new directions. Public Administration and Development: The International fournal of Management Research and Practice, 22(1), 3-18. https://doi.org/10.1002/pad.202

Broadbent, J., \& Guthrie, J. (2008). Public sector to public services: 20 years of 'contextual' accounting research. Accounting, Auditing \& Accountability fournal, 21(2), 129-169. https://doi.org/10.1108/09513570810854383

Brøske, B. Å. (2017). Samarbeid mellom kulturskole og grunnskole - expansiv læring eller bistandsarbeid? [Collaboration between the school of music and performing arts and the primary school - expansive learning or development work?]. In E. Angelo, A. Rønningen \& R. J. Rønning (Eds.), Forskning og utvikling 
i kulturskolefeltet. IRIS - den doble regnbuen (Chapter 12). Cappelen Damm Akademisk. https://doi. org/10.23865/noasp. 21

DeVita, C. J., Fleming, C., \& Twombly, E. (2001). Building capacity in nonprofit organizations. The Urban Institute.

Frey, J. H., \& Fontana, A. (1991). The group interview in social research. The Social Science fournal, 28(2), 175-187. https://doi.org/10.1016/0362-3319(91)90003-M

Fuglsang, L. (2008). Capturing the benefits of open innovation in public innovation: A case study. International Fournal of Services Technology and Management, 9(3-4), 234-248. https://doi.org/10.1504/ IJSTM.2008.019705

Gazley, B. (2008). Beyond the contract: The scope and nature of informal government-nonprofit partnerships. Public Administration Review, 68(1), 141-154. https://doi.org/10.1111/j.1540-6210.2007.00844.x

Hallam, R. (2011). Effective partnership working in music education: Principles and practice. International Fournal of Music Education, 29(2), 155-171. https://doi.org/10.1177/0255761410396963

Holst, F. (2016). Samarbejde i Åben Skole - musikaliske fælleskaber i det tredje rum [Collaboration in Open School - musical communities in the third room]. Temahäfte om Åben Skole. Unge Pcedagoger, 3.

Korpsnett. (2021). Medlemskorps [Membership bands]. https://www.korpsnett.no/om-oss/medlemskorps

Lovdata. (2020). Act relating to Primary and Secondary Education and Training (the Education Act). https://lovdata. no/dokument/NLE/lov/1998-07-17-61

Maiello, A., Viegas, C. V., Frey, M., \& Ribeiro, J. L. D. (2013). Public managers as catalysts of knowledge coproduction? Investigating knowledge dynamics in local environmental policy. Environmental Science $\mathcal{E}$ Policy, 27, 141-150. https://doi.org/10.1016/j.envsci.2012.12.007

Najam, A. (2000). The four C's of government third sector-government relations. Nonprofit Management and Leadership, 10(4), 375-396. https://doi.org/10.1002/nml.10403

Norges Musikkorps Forbund. (2021). Medlemsstatistikk Norges Musikkorps Forbund 2019 [Memberhips Statistics The Norwegian Band Federation 2019]. https:/www.mynewsdesk.com/no/norges-musikkorps-forbund/ documents/medlemsstatistikk-norges-musikkorps-forbund-2019-93270

Oakes, H., \& Berry, A. (2009). Accounting colonization: Three case studies in further education. Critical Perspectives on Accounting, 20(3), 343-378. https://doi.org/10.1016/j.cpa.2007.06.006

Osborne, S. P., Radnor, Z., \& Strokosch, K. (2016). Co-production and the co-creation of value in public services: a suitable case for treatment? Public Management Review, 18(5), 639-653. http://dx.doi.org/10. 1080/14719037.2015.1111927

Ostrom, E. (1972). Metropolitan reform: Propositions derived from two traditions. Social Science Quarterly, 53(3), 474-493.

Ostrom, E. (1996). Crossing the great divide: Coproduction, synergy, and development. World Development, 24(6), 1073-1087. https://doi.org/10.1016/0305-750x(96)00023-x

Pestoff, V. (2006). Citizens and co-production of welfare services: Childcare in eight European countries. Public Management Review, 8(4), 503-519. https://doi.org/10.1080/14719030601022882

Robinson, M. (1998). A collaboration model for school and community music education. Arts Education Policy Review, 100(2), 32-39. https://doi.org/10.1080/10632919809599454

Russell, J. L., Knutson, K., \& Crowley, K. (2013). Informal learning organizations as part of an educational ecology: Lessons from collaboration across the formal-informal divide. Fournal of Educational Change, 14(3), 259-281. https://doi.org/10.1007/s10833-012-9203-4

Simons, H. (2009). Whose data are they? Ethics in case study research. Case study research in practice (pp. 96-113). SAGE Publications. https://doi.org/10.4135/9781446268322.n6

The Ministry of Culture. (2013). NOU 2013:4 Kulturutredningen 2014 (Official Norwegian Report on cultural policy). The Ministry of Culture. https://www.regjeringen.no/no/dokumenter/nou-2013-4/id715404/

The Norwegian Council for Schools of Music and Performing Arts. (2016). Curriculum framezork for schools of music and performing arts: Diversity and deeper understanding. The Norwegian Council for Schools of Music and Performing Arts. https://www.google.com/url?client=internal-element-cse\&cx=0060099216 10740668934:pr5ids5iiis\&q=https://www.kulturskoleradet.no/_extension/media/6679/orig/attachment/ Rammeplan\%2520engelsk\%2520versjon.pdf\&sa=U\&ved=2ahUKEwiB_qK3gPvwAhXwmIsKHbboD DEQFjAAegQIBBAB\&usg=AOvVaw1FNHMKOTtxc9317FcBM0Pp

Väkevä, L., Westerlund, H., \& Ilmola-Sheppard, L. (2017). Social innovations in music education: Creating institutional resilience for increasing social justice. Action, Criticism, and Theory for Music Education, 16(3), 129-147. https://doi.org/10.22176/act16.3.129

Voorberg, W. H., Bekkers, V. J., \& Tummers, L. G. (2015). A systematic review of co-creation and co-production: embarking on the social innovation journey. Public Management Review, 17(9), 1333-1357. https://doi.org/ $10.1080 / 14719037.2014 .930505$ 